\title{
Hypersensitivity to Procarbazine and Severe RSV Pneumonia in a Child with Hodgkin's Lymphoma
}

\author{
Dilek INCE ${ }^{1}$, Duygu OLMEZ ${ }^{2}$, Tolga F. KOROGLU ${ }^{3}$, Arzu B. HOCAOGLU ${ }^{2}$, Secil A. CAMLAR ${ }^{4}$, \\ Kamer M. UYSAL ${ }^{1}$, Nevin UZUNER ${ }^{2}$, Nur OLGUN ${ }^{1}$ \\ ' Dokuz Eylul University Institute of Oncology, Department of Pediatric Oncology, Izmir, Turkey \\ ${ }^{2}$ Dokuz Eylul University, Faculty of Medicine, Department of Pediatric Allergy, Izmir, Turkey \\ ${ }^{3}$ Dokuz Eylul University, Faculty of Medicine, Department of Pediatrics, Pediatric Intensive Care Unit, Izmir, Turkey \\ ${ }^{4}$ Dokuz Eylul University, Faculty of Medicine, Department of Pediatrics, Izmir, Turkey
}

\begin{abstract}
Herein we report respiratory syncytial virus (RSV) pneumonia in a child who had hypersensitivity to procarbazine. Urticarial plaques, maculopapular rash occurred in a child with Hodgkin's lymphoma while receiving procarbazine. Clinical improvement was achieved by withdrawal of procarbazine, administration of corticosteroids, diphenhydramine. After receiving the next course with bleomycin containing chemotherapy, RSV pneumonia developed which required prolonged mechanical ventilation and was treated with oral ribavirin. Hypersensitivity to procarbazine can be a life treating condition. Omitting procarbazine may be necessary. Respiratory syncytial virus pneumonia in the setting of both immunsupression and procarbazine / bleomycin toxicity may have a more serious course.
\end{abstract}

Keywords: Procarbazine, Chemotherapy, Hypersensitivity, Skin reaction, Pulmonary toxicity, Treatment, Child, Respiratory Syncytial virus, Pneumonia

ÖZET

Hodgkin Lenfomalı Bir Çocukta Gelişen Prokarbazin Hipersensitivitesi ve Ağır RSV Pnömonisi

Prokarbazin hipersensitivitesi olan bir çocukta gelişen respiratuar sinsityal virus (RSV) pnömonisi bildirildi. Hodgkin lenfomaI bir çocukta prokarbazin alıyorken ürtiker plakları, makülopapüler döküntü gelişti. Prokarbazinin kesilmesi, kortikosteroid ve difenhidramin uygulamalarılla klinik iyileşme sağlandı. Bir sonraki kemoterapi küründe bleomisin içeren şema uygulandıktan sonra hastada uzun süreli mekanik ventilasyon gerektiren RSV pnömonisi gelişti ve oral ribavirin ile tedavi edildi. Prokarbazin hipersensitivitesi hayatı tehdit edebilen bir tablodur. Prokarbazinin tedaviden çıkarımasını gerektirebilir. İmmün baskılanma, prokarbazin / bleomisin toksisiteleri zemininde gelişen RSV pnömonisi çok daha ağır seyredebilir.

Anahtar Kelimeler: Prokarbazin, Kemoterapi, Hipersensitivite, Deri reaksiyonu, Pulmoner toksisite, Tedavit, Çocuk, Respiratuar sinsityal virus, Pnömoni 


\section{INTRODUCTION}

Procarbazine related hypersensitivity reactions including fever, skin reactions, and pulmonary toxicity have been reported rarely. ${ }^{1-13}$ Hypersensitivity to procarbazine is particularly uncommon during childhood.$^{6-8}$ Here we report on a child with Hodgkin's lymphoma (HL) who developed procarbazine induced skin hypersensitivity reactions, and then severe pneumonia due to the respiratory syncytial virus (RSV) while receiving procarbazine, and bleomycin containing chemotherapy.

\section{CASE REPORT}

A 5 years-old boy was diagnosed with stage 4 HL. He had cervical, supraclavicular and mediastinal lymphadenopathies with bone marrow involvement, and also B symptoms (fever and night sweats) were positive. Anticancer treatment was initiated with COPP (cylophosphamide, vincristine, prednisolone, procarbazine). This chemotherapy was preferred to avoid anthracycline containing regimens since he had aortic stenosis. The first two courses of COPP regimen were complicated with significant weight gain, glucose intolerance, and hypertension related to prednisolone therapy. At the 6th day of the third COPP course, widespread urticarial plaques and maculopapular rashes developed over the whole body within a few hours after taking procarbazine. He was on steroid therapy when skin reactions occurred. Prednisolone was continued, diphenhydramine was added. Clinical improvement was observed within 48 hours. Procarbazine was removed from the treatment because of the potential anaphylactic hypersensitivity reaction and pulmonary toxicity risk. The third chemotherapy course was completed without procarbazine. Chemotherapy was then switched to ABVD (adriamycin, bleomycin, vincristine, dacarbazine).

On the 10th day of the first ABVD course (also, at the 25th day of the last procarbazine dose) he was admitted due to neutropenic fever, and tachypnea. Lymphocyte counts were $510 \mathrm{cell} / \mathrm{mm}^{3}$. Chest radiograph on admission showed diffuse bilaterally interstitial pneumonic infiltrations (Figure 1a). He was started on meropenem, amikacin, teicoplanin, clarithromycin, and trimethoprim sulfamethoxazole.
In the following 12 hours, his condition deteriorated rapidly and he developed respiratory distress. $\mathrm{He}$ required intubation and mechanical ventilation. Chest radiographies revealed a rapid progression of pneumonic infiltrates and subsequently a diagnosis of acute respiratory distress syndrome (ARDS) was made (Figure 1a, b, c). Amphotericin B was added to the treatment. Viral secretions tested positive for RSV. Ribavirin (oral, $15 \mathrm{mg} / \mathrm{kg} /$ day), intravenous (IV) palivizumab were administered. RSV was confirmed by cell culture, and antigen continued to test positive for 2 weeks. Serum Mycoplasma and Chlamydia antibodies were negative. Bacterial cultures of blood, urine and tracheal secretions remained negative. There was no evidence of a Pneumocystis carinii infection. He remained intubated for three weeks in the pediatric intensive care unit and was discharged on the 28th hospital day. Radiological findings completely regressed after three months (Figure 1d).

\section{DISCUSSION}

Hypersensitivity reactions due to anticancer drugs could be serious and even life treating. While these reactions are well known side effects for some certain chemotherapeutics, procarbazine related hypersensitivity reactions including fever, skin reactions, and pulmonary reactions have been reported uncommonly. ${ }^{1-13}$ Procarbazine is effectively used in combination chemotherapy regimens for treatment of HL.

We reported occurrence of maculopapular rash and urticarial plaques due to procarbazine in a 5 years old boy with HL. This boy developed skin reaction at the third COPP course while he was receiving prednisolone, procarbazine. It is difficult to differentiate responsible drugs of an allergic reaction when several drugs are used together. Cyclophosphamide and vincristine had been administered six days before this reaction, and skin hypersensitivity developed after taking procarbazine. So procarbazine was thought that the responsible drug and it was discontinued; corticosteroids and diphenhydramine were administered. Procarbazine related skin reactions include maculopapular and urticarial rashes, angioedema, and fixed drug eruption. ${ }^{1-6}$ Procarbazine related rashes can occur during the first, second or third course of chemotherap. ${ }^{2,11}$ These reactions 


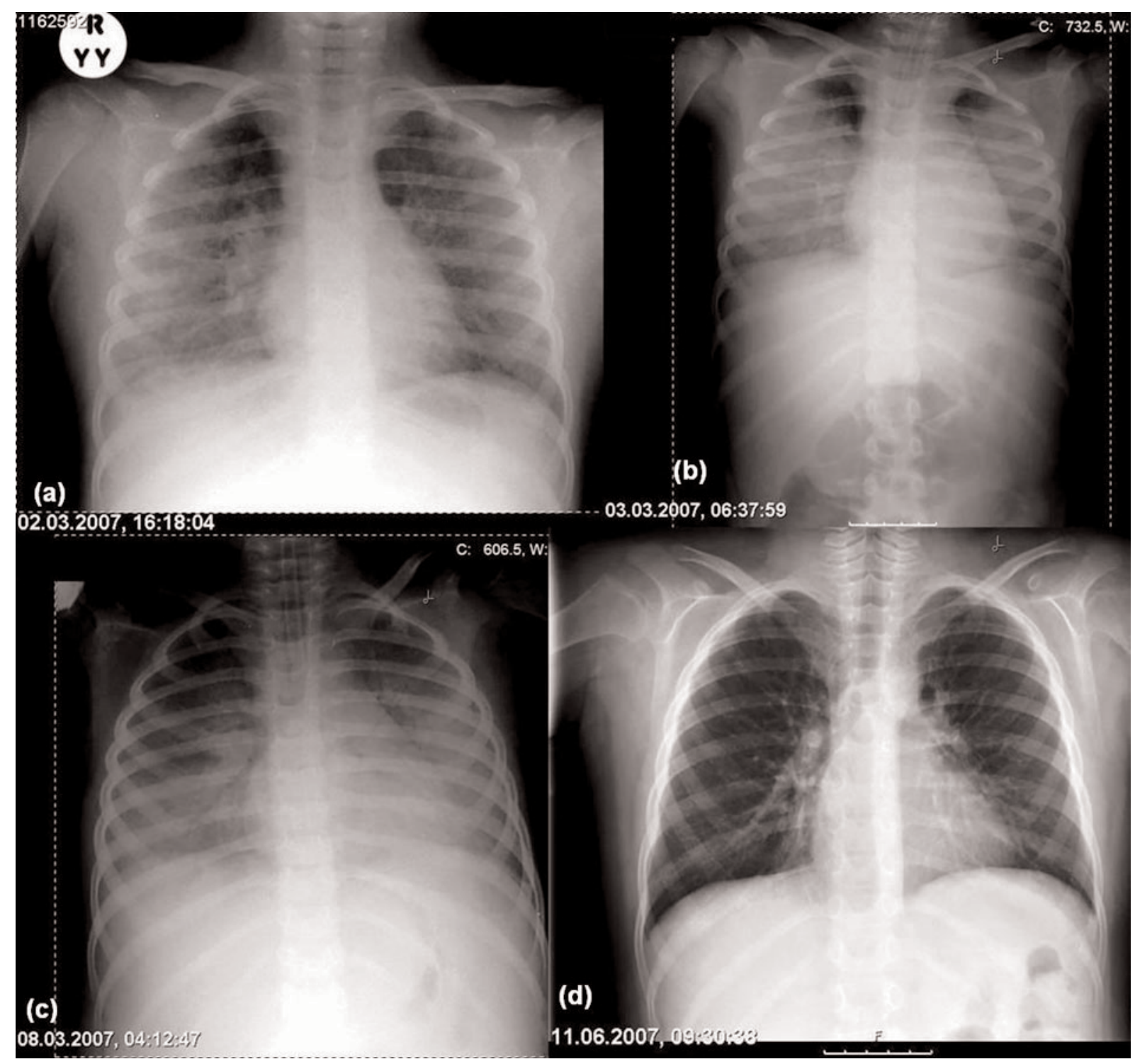

Figure 1 (a, b, c) On the 1st, 2nd, and 6th days of admission with febrile neutropenic episode, chest radiographs were showing rapidly progressive bilaterally alveolar, interstitial pulmonary infiltrations. (d) The normal chest X ray that was taken after 3 months of treatment can be seen below.

can even occur in a steroid-induced immunosupression phase. ${ }^{1,2}$ Hypersensitivity reactions due to procarbazine have been reported rarely during childhood..$^{6.8}$ Coyle et. al. suggested that the lower incidence of skin hypersensitivity due to procarbazine in patients with HL might be explained by deficits in cellular immunity in these patients. ${ }^{2}$

While pulmonary hypersensitivity is a well recognised toxicity of several anticancer drugs, particularly bleomycin, busulfan, methotrexate, and carmustine; procarbazine related pulmonary toxicity has been only rarely reported. ${ }^{2,3,8-13}$ Acute or delayed serious, even life-treating, pulmonary toxicity due to procarbazine can occur and may lead to reversible or permanent pulmonary damage..$^{2,38-13}$ Delayed life threating pneumonitis due to rechallange with procarbazine in patients who initially had skin hypersensitivity reactions to procarbazine had been reported. ${ }^{2.9}$ Therefore, we omitted procarbazine while planning a different chemotherapy regimen, although there was conflicting views about withdrawal of procarbazine due to skin hypersensitivity. ${ }^{2,11}$ 
Neutropenic fever and ARDS occurred at the 25th day of the last procarbazine dose however; he also received bleomycin as part of the second regimen just 10 days before this complication. Several factors might be related to this clinical condition including Hodgkin and/or chemotherapy related immunosupression, infectious agents and/or pulmonary toxicity of chemotherapeutics that he received (bleomycin, procarbazine). He received empirical broad spectrum antimicrobial therapy and required supportive mechanical ventilation for three weeks.

Steroids have been used for the treatment of pulmonary infiltrations related to procarbazine hypersensitivity. ${ }^{9-12}$ We did not give him corticosteroid therapy for the management of pneumonitis because RSV was documented during a febrile neutropenic episode. In pediatric oncology patients RSV infections have been uncommonly reported..$^{15-19}$ Lymphopenia and young age were described as risk factors for severe RSV related lower respiratory tract infections, in children with cancer. ${ }^{19}$ Although our patient didn't receive any further procarbazine after the skin hypersensitivity reaction, previous procarbazine doses might have contributed to the pulmonary reaction. He also received a well known pulmonary toxic agent, bleomycin, just ten days before this pulmonary complication. Therefore, both of these agents might have contributed to the severe pneumonitis. Besides receiving pulmonary toxic agents, impaired cell mediated immunity related to HL might also contribute to the development of severe RSV infection in this case.

Mild clinical course in RSV infections have been reported in 18 children with cancer. ${ }^{17}$ However 12 of 18 patients had malignant solid tumors in this study. ${ }^{17}$ It has been reported that, RSV infections can lead to serious morbidity and even mortality particularly in children who were treated for acute leukemias and who were undergoing hematopoietic stem cell transplantation. ${ }^{18,19}$ In previous reports, ribavirin was given by inhaled and/or IV routes for treatment of RSV infections in children with cancer. ${ }^{16,17}$ Our patient received oral ribavirin because IV form isn't available in our country, and he was successfully treated by oral ribavirin and IV palivizumab. In addition to ribavirin, RSV-immunoglobulin or palivizumab was given for high risk children, particularly at younger ages..$^{17,20}$
Skin hypersensitivity reactions related to procarbazine could be treated with corticosteroids and withdrawal of procarbazine. There are conflicting suggestions about removal of procarbazine from anticancer treatment due to skin hypersensitivity. ${ }^{2,11}$ Previously, severe pulmonary toxicity was reported in case procarbazine was continued after the development of skin hypersensitivity. ${ }^{2,89}$ In patients who develop pulmonary infiltrations while receiving procarbazine, procarbazine related pulmonary hypersensitivity should be considered in differential diagnosis. It should be kept in mind that procarbazine related hypersensitivity and subsequent pulmonary toxicity can be a life treating condition. Omitting procarbazine may be necessary. Respiratory syncytial virus pneumonia in the setting of both immunsupression and procarbazine / bleomycin toxicity may have a more serious course.

\section{REFERENCES}

1. Weiss RB, Bruno S. Hypersensitivity reactions to cancer chemotherapeutic agents. Ann Intern Med 94: 6672, 1981.

2. Coyle T, Bushunow P, Winfield J, Wright J, Graziano S. Hypersensitivity reactions to procarbazine with mechlorethamine, vincristine, and procarbazine chemotherapy in the treatment of glioma. Cancer 69: 2532-40, 1992.

3. Jones SE, Moore M, Blank N, Castellino RA. Hypersensitivity to procarbazine (Matulane) manifested by fever and pleuropulmonary reaction. Cancer 29: 498500, 1972.

4. Glovsky MM, Braundwald J, Opelz G, Alenty A. Hypersensitivity to procarbazine associated with angioedema, urticaria, and low serum complement activity. J Allery Clin Immunol 57: 134-140, 1976.

5. Andersen E, Videbaek A. Procarbazine-induced skin reactions in Hodgkin's disease and other malignant lymphomas. Scand J Haematol 24: 149-51, 1980.

6. Giguere JK, Douglas DM, Lupton GP, Baker JR, Weiss RB. Procarbazine hypersensitivity manifested as a fixed drug eruption. Med Pediatr Oncol 16: 378-380, 1988.

7. Akyol H, Sarialioglu F, Buyukpamukcu M, Akyuz C. Cytotoxic drug-induced fever: A report on procarbazine-induced hyperprexia. Med Pediatr Oncol 18: 173$175,1990$.

8. Garbes ID, Henderson ES. Procarbazine-induced interstitial pneumonitis with a normal chest $x$-ray: a case report. Med Pediatr Oncol 14: 238-241, 1986. 
9. Brooks B, Hendler N, Alvarez S, Ancalmo N, Grinton S. Delayed life-threating pneumonitis secondary to procarbazine. Ann Clin Oncol 13: 244-246, 1990.

10. Lewis LD. Procarbazine associated alveolitis. Thorax 39: 206-207, 1984.

11. Mahmood T, Mudad R. Pulmonary Toxicity Secondary to Procarbazine. Am J Clin Oncol (CCT) 25: 187-188, 2002.

12. Cersosimo RJ, Licciardello JT, Matthews SJ, Bromer R, Hong WK. Acute pneumonitis associated with MOPP chemotherapy of Hodgkin's disease. Drug Intel Clin Pharm 18: 609-611, 1984.

13. Millward MJ, Cohney SJ, Byrne MJ, Ryan GF. Pulmonary toxicity following MOPP chemotherapy. Aust N Z J Med 20: 245-248, 1990.

14. Lanzkowsky P. Hodgkin disease. In: Lanzkowsky P., editor. Manual of Pediatric Hematology and Oncology. California: Elsevier Academic Pres; 2005. p 453 - 490.

15. Hall CB, Powell KR, MacDonald NE, Gala CL, Menegus ME, Suffin SC, Cohen HJ. Respiratory syncytial viral infection in children with compromised immune function. N Engl J Med 315: 77-81, 1986.

16. Vettenranta K, Ukkonen P, Saarinen UM. RSV infection complicating the therapy of pediatric malignancies: report of six cases. Med Pediatr Oncol 26: 261 3, 1996.

17. Cole PD, Suh JS, Onel K, Stiles J, Armstrong D, Dunkel IJ. Benign outcome of RSV infection in children with cancer. Med Pediatr Oncol 37: 24-29, 2001.

18. Sung L, Alonzo TA, Gerbing RB. Respiratory syncytial virus infections in children with acute myeloid leukemia: A report from the Children's Oncology Group. Pediatr Blood Cancer 51:784-786, 2008.
19. El Saleeby CM, Somes GW, DeVincenzo JP, Gaur AH. Risk factors for severe respiratory syncytial virus disease in children with cancer: the importance of lymphopenia and young age. Pediatrics 121: 235-43, 2008.

20. Chávez-Bueno S, Mejías A, Merryman RA, et al. Intravenous palivizumab and ribavirin combination for respiratory syncytial virus disease in high-risk pediatric patients. Pediatr Infect Dis J 26: 1089-93, 2007.

\section{Correspondence}

Dr. Dilek INCE

Dokuz Eylül Üniversitesi, Onkoloji Enstitüsü

Pediatrik Onkoloji Anabilim Dalı

Mithatpasa Caddesi No: 1606

35340, İnciraltı

İzmir / TURKEY

Phone: (+90.232) 4124887

Fax: $\quad(+90.232) 2771020$

e-mail : dilek.ince@deu.edu.tr 